\title{
GCU
}

Glasgow Caledonian

University

University for the Common Good

\section{Developing a sustainability KM strategy for HA planned works}

\author{
Leblanc, Herve; Thomson, Craig; Cameron, lain
}

Published in:

Proceedings of the ICE - Management, Procurement and Law

DOI:

10.1680/mpal.14.00024

Publication date:

2015

Document Version

Author accepted manuscript

Link to publication in ResearchOnline

Citation for published version (Harvard):

Leblanc, H, Thomson, C \& Cameron, I 2015, 'Developing a sustainability KM strategy for HA planned works', Proceedings of the ICE - Management, Procurement and Law, vol. 168, no. 2, pp. 49-65.

https://doi.org/10.1680/mpal.14.00024

\section{General rights}

Copyright and moral rights for the publications made accessible in the public portal are retained by the authors and/or other copyright owners and it is a condition of accessing publications that users recognise and abide by the legal requirements associated with these rights.

Take down policy

If you believe that this document breaches copyright please view our takedown policy at https://edshare.gcu.ac.uk/id/eprint/5179 for details of how to contact us. 


\section{Developing a sustainability KM strategy for HA planned works}

Authors

Dr Herve Leblanc DUT, BSc, MSc (dist), PhD, Coordinateur maintenance EPI categorie 3, France-Securite, Nantes, France.E-mail: herve_leblanc@ hotmail.fr

*Dr Craig Thomson MA(hons), MRes, PhD, PgC LTHE, FHEA, Lecturer in Sustainability and the Built Environment, School of Engineering and Built Environment, Glasgow Caledonian University, City Campus, Cowcaddens Road, Glasgow, G4 0BA, Telephone 0141331 3016, Fax 0141331 3696, E-mail: craig.thomson@gcu.ac.uk

Professor Iain Cameron BSc, MSc, PhD, FCIOB, FCMI, CFIOSH, FHEA, FRSA, Dean of School of Engineering and Built Environment, Glasgow Caledonian University, City Campus, Cowcaddens Road, G4 OBA, Telephone 0141331 3297, Fax 0141331 3696, Email: i.cameron@gcu.ac.uk.

*Corresponding author Dr Craig Thomson.

Key words: Knowledge management, Planned works, Social housing, Housing Association, Sustainability.

1 figures, 5 tables and 3 appendix 


\section{Developing a sustainability-related knowledge management strategy for housing association planned works}

The effective management of sustainability-related knowledge appears central to the development of sustainable construction practices. Despite progress in other contexts, existing knowledge management efforts have been of limited value to contexts such as Housing Association (HA) planned works (cyclical replacement of housing components) due to an inability to reflect the specificities of these projects. This paper presents the development of a structured strategy to improve the capture, storage, retrieval and exchange of sustainability-related knowledge within HA planned works. Knowledge mapping exercises based on semi-structured interviews were carried out within four different sized Scottish HAs. Sustainability-related knowledge maps were developed for each activity focusing on managerial, economic, social, environmental aspects and overall flow of knowledge providing the basis for recommendations to improve the management of sustainability-related knowledge during planned works. The strategy promotes a structured approach enabling HA's the opportunity to tailor the strategy to reflect their context and requirements. Practitioners from the case studies confirmed its usefulness especially for HA's committed to sustainability but struggling to engage with high level policy and strategies. One case study has implemented the high level principles to support their wider HA sustainability policy and are piloting a strategy for their planned works.

Keywords: Knowledge management, Planned works, Social housing, Housing Association, Sustainability. 


\section{Introduction}

Like the rest of U.K., the Scottish social housing sector is mainly managed by Local Authorities (LAs) (a full glossary of abbreviations is provided in Appendix 1) and Registered Social Landlords (RSL's) predominantly Housing Associations (HAs) which represent between them 594,000 dwellings or some $24.1 \%$ of the Scottish housing stock (The Scottish Government, 2011). The provision of social housing which meets the needs of current and future generations is a key concern for national planning especially given the poor condition of the current stock, and rising and changing demands for social housing (GROS, 2010; Christie, 2011). In meeting these challenges, the choices available to social housing providers are heavily shaped by a lack of policy for social housing, decreasing budgets and a lack of finance for new build solutions or large refurbishment projects (UK Green Building Council, 2008; Audit Commission, 2010). As a consequence, maintenance and more precisely planned works (defined by the cyclical replacement of internal and external housing components) have been at the centre of efforts to adapt and modernise the social housing stock (The Scottish Housing Regulator, 2010).

In developing its housing stock, social landlords have a responsibility to align with national carbon reduction targets and reduce the environmental, social and economic impacts of buildings and their development processes (The Scottish Government, 2013). Whilst a series of planning and building regulation changes are raising the sustainability standards of new build housing, the key challenge remains to improve the existing housing stock through renovation, refurbishment and maintenance across all sectors (Sullivan, 2007; BERR, 2008; Turcotte and Geiser, 2010). With the short term emphasis on maintenance (planned works) within social housing there is a need to ensure the strategies and practices of teams managing its delivery align with the sustainable construction agenda (Jones and Cooper, 2007). 
HA maintenance can be understood in the context of belonging to two categories: planned and reactive works. Planned works are based on stock condition information and component lifecycle while reactive works are carried out after a tenant reports a problem such as a water leak or broken window. This research focuses on planned works as they provide wider potential to inform management processes and practices compared to reactive repairs which by nature are unpredictable.

Although LAs remain the largest provider of social housing in the UK, the authors focus on HAs given the growing number of stock transfers, their not-for-profit status, greater financial flexibility, and commitment to improving the life of their tenants (Harriott and Matthews, 2004). The UK Government has recognised the potential of HA's to lead the domestic housing sector in adopting sustainable practices progress through their Sustainable Public Procurement agenda (Strategic Forum for Construction (SFC), 2008) and in several HA focused reports (Housing Corporation, 2003; Sustainable Homes, 2007). Indeed, since 2002 HA's in Scotland have been required to have a sustainability policy and action plan and reflect these in funding applications, however these have remained slow to filter down to operational level.

Whilst HA practitioners are demonstrating a growing awareness of sustainability, the rate of change in practice remains slow due to a lack of understanding regarding the implications or actions required to deliver sustainability policies (Hall and Purchase, 2006; Fenner et al., 2006; Carter and Fortune, 2008, Wolstenholme, 2009). Research relating to social housing has tended to focus on delivering sustainability in new build properties and to a lesser extent refurbishment/ renovation projects; but planned works projects remains a research gap (Power, 2010; Sharp and Jones, 2012). 
Despite a growing awareness of the importance of managing sustainability-related knowledge within construction practices (Hamel and Pralahad, 1994; Shelbourn et al., 2006; Renukappa and Egbu, 2007) insufficient emphasis is placed on planned works within social housing (Malone and Yohe, 2002). Knowledge Management (KM) strategies and solutions have been developed over the years to help organisations in all sectors become more knowledge-centred (Renukappa and Egbu, 2007). This represents broad guidance which is difficult to apply within specific sectors such as social housing and especially in poorly investigated processes such as planned works. In fact, many researchers argue that managing sustainability-related knowledge is an integrated and complex process dependent on a KM strategy which is contextualised for the sector and requires integration with practice (Lichtenstein and Swatman, 2003). Existing HA KM and sustainability strategies fail to address the specific demands of planned works, and as a result a need exits to establish an understanding of how HA practitioners manage sustainability-related knowledge during such projects with a view to developing a specific strategy to meet their practice based needs. This research aims to outline the development of a Sustainability-related Knowledge Management Strategy (SKMS) for HA planned works, founded on the analysis of process and knowledge mapping exercises within four contrasting case studies.

\section{Interpretation of sustainability}

Sustainability in the social housing sector can be interpreted differently depending on the context it is used. It is often related with improving environmental performance, but it can also be linked to affordable housing, fuel poverty, health and social care, and sustainable communities. This research aims to align with the broader definition of sustainability reflecting environmental, social and economic dimensions as in the World Commission on Environmental Development definition (WCED, 1987). Table 1 shows the findings of a 
review of existing research and documents related to sustainability in the context of social housing and interprets the sustainability objectives sought through the delivery of planned works projects.

INSERT Table 1: Sustainability objectives for housing adapted for HA planned works (adapted from Vanegas et al., 1995 and Williams and Dair, 2006).

\section{Managing sustainability-related knowledge}

It is possible to distinguish two schools of thought for knowledge management. Firstly, those who concentrate on the benefits an organisation can derive from managing its knowledge usually through information technology and secondly those focusing on the control of KM process through management issues (Offsey, 1997; Al-Ghassani et al., 2004). In the former, knowledge is considered as an 'object' existing in a number of forms and locations and recognised as the 'functionalist' perspective. Nonaka and Takeuchi (1995) reflect this by categorising knowledge as either tacit or explicit, an approach criticised by some for its simplicity and for not addressing the complexity of knowledge creation (Venters, 2002). The vast majority of construction related $\mathrm{KM}$ strategies reflect this perspective as they aim to capture and reuse knowledge between contexts (projects) and therefore address the 'reinventing wheel' syndrome often described as a barrier to improvement. Its ability to provide distinctions between knowledge forms has potential to help practitioners identify and manage sustainability-related knowledge (C-Sand, 2011). However, this perspective often struggles to reflect the dynamism of knowledge that is socially centred and not located in one location (Schultze, 1998). The interpretivist perspective acknowledges that knowledge is considered "not to exist independent of the human experience, social practice, knowledge and knowledge use and where such knowledge is shaped by the social practices of communities of individuals" (Venters, 2002). This research suggests that whilst it is important to draw on 
techniques and categories aligned with the functionalist perspective, it requires to primarily reflect the socially constructed and dynamism of the interpretivist perspective.

HA practitioners struggle to integrate sustainability into practice because existing guidance provided by government or professional bodies is often too generic and lacking context. Indeed even HA's own sustainability strategy and action plans often reflect the strategic level and are not related to the operational considerations of planned works projects (Carter and Fortune, 2008). To be successful a SKMS needs to reflect the activities of a planned work project and be reflective of project context. As a starting point, a process model for the planned works project is required but on starting this research a generic interpretation of the process did not exist. The Planned Work Process Model (PWPM) published in Leblanc et al. (2013) was developed during a previous stage of this research (using the same case studies) forming the structure of the SKMS.

The authors adopt the view that a SKMS should focus on improving the existing creation, capture and use of sustainability-related knowledge without adding to the workloads of the HA practitioner. In this sense, the SKMS aims to develop mechanisms facilitating sustainability-related knowledge exchange, storage and re-use within practice, as opposed to a system that would aim to do the same but that would appear as an add-on to practice and seen as a 'burden'. This approach also intends to manage the dynamism of knowledge discussed by Egbu et al. (2006), with the SKMS emphasising mechanisms to ensure the continuous creation and management of sustainability-related knowledge during planned works. To resume the SKMS will aim to improve:

- The re-use of sustainability-related knowledge: encourage the re-use of ideas and processes and prevent the 're-invention of the wheel'. 
- The access to sustainability-related knowledge: locate knowledge in processes, relationships, policies, people, repositories and context.

- The sustainability-related knowledge flow: identify and remove barriers to knowledge flow within and across HAs.

- The connection between practitioners in HAs planned works: connect practitioners with each other and/or help to identify relevant sustainability experts (holders of knowledge).

\section{Research strategy and methods}

An emergent approach (interpretivist) is adopted to guide the development of the research strategy with a view to reflecting context and practice ensuring knowledge is seen as part of social interaction (Guo and Sheffield, 2006). However, in order to reflect the need to capture, store and reuse knowledge demanded by practitioners, categories of knowledge will be used to help inform the analysis. Although more associated with a functionalist perspective, it will enable paradigm interplay which is encouraged by many researchers (Hassard, 1988; Gioia and Pitre, 1990; Willmott, 1993). As a result, this research aims to develop a SKMS which is usable for practitioners but also reflects the dynamic nature of knowledge.

\section{Knowledge mapping}

Knowledge mapping (Kmaps) represents the primary activity when developing a KM strategy (Vestal, 2005; Egbu, 2006; Eppler, 2008) and is applied to map the sustainabilityrelated knowledge used and exchanged by practitioners' during HA planned works projects, but also to understand the dynamics of its flow and to consider its management requirements in order to provide the basis for the SKMS. 
Caldwell (2002) distinguishes Kmaps into four common categories: procedural, conceptual, competency and social network analysis. This research aligns with social network analysis in its mapping, reflecting what Eppler (2008) describes as the application of knowledge (i.e. its transfer, sharing and communication between HA planned works practitioners). The preliminary stage involved a process mapping exercise to establish the PWPM displayed in Appendix 2 and explored in Leblanc et al. (2013) and this provided the basis around which the application of knowledge can be mapped. This approach is similar to work of Egbu et al. (2006) or Thomson et al. (2010) and reflects the need to ensure that practitioners 'realities' of practice are central effectively capturing the flow of knowledge (interpretivist), but also utilising categories to help differentiate the types of knowledge (functionalist).

\section{Knowledge mapping content}

Knowledge can be defined as the facts, information, skills, and understanding that one acquires over time through learning or experience (Matsumoto et al., 2005). Nonaka and Takeuchi (1995) defined two categories of knowledge as explicit and tacit, however alternative representations have been provided reflecting the addition of implicit knowledge (i.e. Vestal, 2005). Explicit knowledge is codified and digitised for example in books, documents, reports, white papers, spreadsheets, memos and databases (Awad and Ghaziri, 2003). Tacit knowledge is not easily transformable and defined as 'know-how', past experiences, expertise, through interaction between individuals and through the memories of others (Egbu, 2004; Thomson et al., 2011). Finally implicit knowledge corresponds to the part of tacit knowledge that can be easily transformed into explicit form (such as opinion and idea) (Frappaolo, 2008). Implicit knowledge can be captured and written down only when the full depth of the context is understood (Vestal, 2005). Furthermore it can be said that implicit knowledge resides between tacit and explicit knowledge in the 'middle ground' 
(Frappaolo, 2008). Although the above definitions of explicit, tacit and implicit knowledge are widely accepted the lack of clear distinction between implicit and tacit complicates the task of knowledge mapping. To avoid any confusion and for the sake of clarity, in this research tacit knowledge is reflected as the knowledge that resides in practitioners' minds which cannot be shared while implicit knowledge indicates the part of the practitioner tacit knowledge that can be shared through discussion or transformed into explicit form.

\section{Knowledge map representation}

Kmaps are cognitive maps which are "representations of an individual's perception of a particular topic" (Scavarda et al., 2004). Cognitive maps have nodes that represent a concept, variable, issue, entity, or attribute and these can be represented by a single word, phrase or paragraph. Kmaps also have links which represent the relationships between the nodes (Folkes, 2004) stressed in social network analysis. O’Donnell et al. (2002) explain that Kmaps can be distinguished from other similar cognitive representations such as concept or mind maps because of the use of a set of labelled links that connect nodes. McCagg and Dansereau (1991) describe three categories of links as dynamic (changing relationship between ideas), static (structural relationship between ideas) and elaborative (extend information). However, no strict Kmap representation guidelines exist and they are not rigidly defined, according to Fisher et al. (2001) they "may theoretically take any form and be used for any number of purposes, the forms and purposes being limited only by the cognitive abilities of the map producers and users." As a result, the researcher needs to develop its own design reflecting the context of its research and with the main criteria being that it adds knowledge (Vail, 1999).

As a result, the Kmaps will contain the following: 
- HA planned work practitioners exchanging, consulting or storing sustainabilityrelated knowledge.

- Sustainability-related dimension of knowledge.

- Knowledge type (explicit, tacit and implicit).

\section{A multiple case study approach}

A multiple case study approach was adopted to compare management approaches to sustainability-related knowledge amongst a cross section of HA contexts. The analysis led to the development of a general strategy for HAs planned works while including specific variations for different HA contexts based on comparison of case studies.

For reasons of accessibility, the data collection was undertaken in Scotland but the HA sector is similar and findings will be generally applicable across the UK (Harriot and Matthews, 2004). Preliminary assessment of the HA sector identified variation in size and type of HA's and an exercise was undertaken to gauge the percentage within the sector displayed in Table 2.

INSERT Table 2 Number and \% of Scottish HAs according to the type and size (adapted from Richardson, 2008; The Scottish Housing Regulator, 2010)

A number of HA's were approached across the typology, with four selected comprising two urban HAs (small and medium) and two stock transfer HAs (medium and large). According to table 2 these HAs cover four categories which represent $67 \%$ of all Scottish HAs and covers the three HA size categories which respectively manage a third of the Scottish HA stock (The Scottish Housing Regulator, 2010). It can be argued that the HA size is a major selection factor as it captures a large number of the practitioners involved in planned works. 'Type' in this context, refers to the nature of the HA stock. Discussions with HA 
practitioners involved revealed that the management of planned works does not dramatically differ between HA types but that size was a more important variable to capture in this research. It was felt that the specialist/rural category and small stock transfer HAs would not represent sufficient difference to justify the time required for a case study.

Across the four HA's, the most common planned works projects undertaken were identified with heating renewals and kitchen renewals representing $17 \%$ and $15 \%$ respectively (Leblanc, 2011), and these provided the focus for knowledge mapping. The selection of practitioners to interview was based on snowballing principles with HA practitioners asked to help identify others who potentially influence or are involved in delivering the projects sustainability (Rice and Ezzy, 1999). Semi-structured interviews (detailed in Case study section) were conducted exploring with respondents the identification of knowledge sources, pathway and receptor for each phase and activity, and their views on its management.

\section{Data analysis}

In accordance with an interpetivist research paradigm the data collected was analysed using coding principles informed by grounded theory. Respondent's answers were openly coded but then classified and mapped to the PWPM phases/activities and other categories such as knowledge type and sustainability dimensions. The research coding strategy favoured Strauss and Corbin's (1990) approach to allow a degree of structure as opposed to Glaser and Strauss's (1967) purest view of coding.

\section{Case studies}

\section{Data collection}

The data collection started during in November 2010 and finished May 2011 with follow up and validation interviews taking place over the following year. Table 3 outlines the case study HAs and type of project studied and table 4 shows respondents. 
INSERT Table 3: Case studies HA and project studied

INSERT Table 4: Case studies respondents and corresponding abbreviation

\section{Knowledge mapping exercise}

The coding of the transcribed interview was divided into separated portions of text. These were assigned a code title and a code reference. The code title briefly described the text reflecting the respondent's vocabulary and the code reference is composed of the respondent abbreviation and a number (illustrated in table 5).

INSERT Table 5: Case study 1 example of codification

The codes were then classified according to the PWPM phases and activities and presented in appendix 2 before being analysed in the following three steps.

1) Codes were assigned a category that emerged from the analysis. Management codes described the practitioner's role and/or action during the kitchen or heating renewal projects. Knowledge codes related to the three types of knowledge: explicit, implicit or tacit. Driver and barrier codes referred to practitioners citing these to an action in a project. Goal codes described practitioners' goals during an activity. It was possible for codes to belong to more than one category.

2) The flow of knowledge and its nature within codes was described. Table 6 presents an example of knowledge analysis of the codes.

INSERT Table 6: Case study 1 example of knowledge analysis of a code

3) Codes were associated to one, two or all sustainability dimensions: social, environment and economic. Based on the analysis, Kmaps for every PWPM phases/activities were then drawn capturing these previous steps. Figure 1 illustrates 'planning phase' Kmap for case study 1. 
The Kmaps were used as the basis to observe the flow and management of the sustainabilityrelated knowledge, how it was captured, stored, retrieved and exchanged between practitioners during planned works.

INSERT Figure 1: Case study 1 'planning phase’ Kmap

\section{Sustainability-related knowledge management strategy (SKMS)}

Comparison of the Kmaps developed from the case studies revealed the following observational themes:

- Management: Practitioners/tenants role and responsibility in the phase/activity.

- Knowledge: The nature of the mapped knowledge and its flow between practitioners/tenants.

- Economic, social and environmental: The amount and scope of related knowledge or goal mapped for the three dimensions within phase /activity.

- Sustainability: The formally identified sustainability dimensions addressed within the phase/activity for comparison against the three dimensions.

Analysis identified a set of good practice that could be recommended to HAs in order to improve the sustainability of planned works. In terms of KM the recommendations were developed based on the strategies of codification and personalisation outlined by Kasvi et al. (2003).

The view was taken that good practice observed in one case study does not have the same 'strength' as good practice observed in two, three of all case studies. As a result, three levels of recommendation for improvements were distinguished: 
- Observations For Improvement (OFI) that emerged from observations from one case study

- Suggestions For Improvement (SFI) that emerged from two, three or all case studies

- Propositions For Improvement (PFI) absent from every case study but suggested by the researchers knowledge of sustainability principles and KM strategies.

It can be said that OFIs and SFIs are potentially more likely to be successfully implemented in HAs practices since they emerged from real life case studies as opposed to PFIs which purely rely on theory. Despite this, PFIs should not be undermined since they rely on basic sustainability principles and on well-established KM strategies widely recognised (Kasvi et al., 2003).

The SKMS displayed in appendix 3 is composed of 17 OFIs, 13 SFIs and 30 PFIs. It should be noted that recommendations for improvements that cannot be attached to a single or cover every HA planned works phase/activity were classified within as general strategy level. Selected recommendations for improvements at the general strategy and individual phase levels are now described to illustrate some of the SKMS key principles.

\section{General strategy level}

\section{Implementing sustainability in every activity}

This section discusses practitioners' considerations of the three sustainability dimensions in the activities of the case studies. It was observed in the four case studies that most activities covered one or two sustainability dimensions but rarely all three. For example, in case study 1 only the activity 'manufacturer selection' demonstrated consideration of the three sustainability dimensions. From this observation it can be argued that to develop sustainable 
practices HAs should consider the three sustainability dimensions during every phase/activity. As a result, the following PFI was proposed:

- The three sustainability dimensions should be considered during all planned works phase/activity.

Following this PFI it can be argued that HAs do not possess the knowledge or time to define the sustainability aspects of all activities. In this sense, the PMO in case study 3 stated that the key to sustainability was to appoint someone to manage all sustainability-related information because other practitioners simply do not have sufficient time. In fact case study 4 already employs an individual tasked of developing sustainable practices, but this relates to a focus on new builds. As a result, one of the solutions to address the three sustainability dimensions during all planned work phases/activities would be to allocate one person to have responsibility for overseeing it. From case study 3, the following OFI was proposed.

- HAs should consider to appoint one person in charge of addressing the three sustainability dimensions during every planned work phase/activity.

Since not all HAs have the financial resources to employ a dedicated staff member to be responsible for managing sustainability within planned works, other potential solutions are required and now discussed. First, HAs could hire a sustainability expert to oversee planned works and to help the HA to develop a sustainability policy and action plan specific to planned works. Hiring sustainability experts to develop sustainable practices has two potential advantages. First, the expert will manage the large amount of information that exists pertaining to sustainable solutions which HA practitioners might struggle with. Second, inviting sustainability experts to ensure a certain standard of quality and credibility appears a sensible option. For example, a consultant was hired in case study 3 to apply for grant funding for an innovative renewable energy project which was secured. This illustrates 
the potential advantage of hiring an external practitioner representing a source of tacit and explicit sustainability-related knowledge not normally available to HA practitioners. Based on the discussion and case study 3 observation the following OFI was proposed:

- HAs should consider hiring sustainability expert to help develop a sustainability policy and action plan and to design innovative projects.

Next, all HAs in each of the case studies hired a contractor and 3 out of 4 hired consultants. An effective way of implanting sustainability into practice would be to include the three sustainability dimensions within the remits of external practitioners. However, this practice was not or limitedly observed in case studies. For example, the selection criteria for the consultant hired in case study 1 was to prepare tenders, prepare project details and specifications and monitor onsite work. The consultant capacity to deliver sustainability within these activities was not a central selection criterion. It can be argued that imposing sustainability criteria to hire contractors and consultants is a potential solution to implementing sustainability into the project. However, as described by the PMO in case study 3 external practitioners must be assessed and monitored to ensure that the sustainability criteria are achieved in practice. Based on this discussion and case study 3 observation the following OFI was proposed:

- HAs should ensure that consultants, contractors and other external practitioners' activities cover the three sustainability dimensions and should monitor its delivery during the project.

One way of potentially monitoring the delivery of sustainability in practice is the development of sustainability-related KPIs which led to the development of a PFI for the Post site phase (described later in this paper).

$\underline{\text { Social housing networking environment }}$ 
The TSM in case study 1 described a strong networking potential between HA's which was not being exploited. He explained that exchanges with other HA practitioners only occur during conferences or at seminars but annual frequency remains low. It can be argued that strong HA networking possibilities should be developed. In addition, the TSM's exchanges with other HA practitioners were mostly concerned with implicit knowledge and potentially lacked the required level of exchange of explicit knowledge. As an illustration of the applicability of such suggestions the PMO in case study 3 explained that he was ready to share a report on innovative testing of renewable energy solutions with other HAs and felt it was mutually beneficial for the community as a whole. Based on case study 1 and 3 the following SFI was proposed:

- HAs should develop exchange of implicit and explicit sustainability-related knowledge with other HAs through formal or informal networks.

The practitioners in case study 1 noted the existence of HA groups where the forum allows practitioners to exchange information. However, these HA groups were observed to mainly have an economic purpose (joint procurement advantages) and induce a loss of management control. It can be said that despite the limitations of the HA groups, the forum represents a privileged place to exchange implicit and explicit sustainability-related knowledge. In KM terms HA forums represent an opportunity to develop a personalisation strategy by facilitating and therefore potentially increasing interactions between practitioners. Based on case study 1 observation and KM personalisation strategy principles the following OFI was proposed:

- HA forums could be developed between independent HAs to exchange implicit and explicit sustainability-related knowledge. 


\section{Phases/activity level}

This section presents one SFI for the planning phase and two PFIs for planned works contract preparation and post site phases for illustrative purposes.

\section{Planning phase (establishment of work priorities)}

It was observed in case studies 3 and 4 that practitioners in charge of planned works establish the annual planned work priorities based on their experience (tacit knowledge), consultation of HA long term plan of work and stock condition information (explicit knowledge) as well as discussion with colleague(s) who have relevant knowledge during a meeting (exchange of implicit knowledge). Since practitioners in charge of planned works in case study 1 and 2 did not meet with colleagues who have relevant knowledge and therefore failed to benefit from personalisation and its associated learning, discussion and mediation, resulting in the researchers developing the following SFI aiming to improve the flow of knowledge-related to stock condition information prior to establishment of work priorities:

- In addition to the consultation of the HA long term plan of work and stock condition information system, HA practitioners should meet with colleagues having relevant knowledge prior to establishing the work priorities.

\section{Contract preparation phase}

It was observed that during the contract preparation phase in case studies 1,3 and 4 sustainability was not a consideration. As argued in the generic strategy practitioners should link this phase with consideration of sustainability. In case studies 1 and 4 , consultants are in charge of the 'project details and work specifications' while in case study 3 the PMO staff are tasked with this. As a result, in case study 1 and 4, HA practitioners who are in charge of planned works could, in principle, require consultants to link the project details and work 
specifications' to the HA sustainability policy and action plan. Similarly, in case study 3 the PMO could link this activity to the HA policy and action plan. However, in practice this was not realised and a clear disconnection observed between high level HA policy and the activities delivered leading to the following PFI:

- HAs should (or require the consultant to) link the 'project details and work specifications' activity to the HA sustainability policy and action plan.

\section{$\underline{\text { Post site }}$}

It emerged from the knowledge mapping exercise that none of the KPI's identified in each case study addressed the environmental sustainability dimension. Following the general strategy all activities should address the three sustainability dimensions. The following PFI was therefore proposed:

- KPIs should include the environmental sustainability dimension.

\section{Practitioners feedback on the SKMS}

The SKMS was presented to the TSM in case study 1 and PMO in case study 3 during January and February 2012. Both recognised the relevance and practicality of the sustainability-related KM recommendations. In fact both explained that they were already focusing on some of the recommendations. For example, the TSM explained that his HA was recently involved in a Quality Efficiency Forum with around 20 HAs meeting every quarter with the goal of facilitating information and knowledge exchange especially around good practice promoting discussion and follow up email communication.

This HA forum aligns with the OFI related to social housing networking environment presented above. Similarly, the PMO in case study 3 explained that in the near future the consultant in charge of the 'asbestos survey' activity will be able to upload the collected 
information directly to the HA system eliminating the transfer through the HA planned work team. The Kmap highlighted the current unnecessary transfer of information from the abestos provider to team who then put upload to the HA system and this was explored in the SFI for 'stock condition/validation survey' activity.

Furthermore the TSM in case study 1 showed interest in several recommendations, but particularly the SFI which suggested a fusion of the tenant decoration allowance and satisfaction survey. The SKMS recommended that merging the surveys would enhance participation and suggests a cash prize for those tenants completing it and they were going to implement this

The feedback provided from respondents enabled reflection on the practicality of the SKMS and amendments were made to its wording, however its contribution was argued to be the degree that it reflected practice.

\section{Limitations and scope for further works}

This research developed a SKMS rooted in practice through case studies. However, there are some shortcomings and limitations. The SKMS aims to address all types and sizes of HAs. In order to reflect the complex HAs landscape, the data collection was designed to reflect the largest proportion of HA categories with in depth case studies utilised but these don't cover minor categories. As a result, some mechanisms of sustainability-related knowledge capture, storage, exchange and retrieval might be missed associated with the context of these categories. The opportunity exists to further improve the SKMS through the expansion of the number of case studies to incorporate minor categories. Expanding upon the number of case studies could enrich the sustainability-related KM observations allowing for a better understanding and leading to the improvement of these recommendations. In addition, practitioners' feedback on the SKMS indicated the need for the researchers to develop 
bespoke strategies adapted to the HAs varying contexts in order to go forward and potentially apply some of the recommendations fully in practice.

"So you need to give me the recommendations. That is something that we may be taken to our committee (sic)" (Case study 1, TSM).

However, despite the need to be tailored it can be said that the presented SKMS provides a starting point for a HA committed to sustainability.

It should be said that the development of a specific SKMS strategy was the focus of further collaboration with the HA represented in case study 1 and this was publicised to the wider HA community through an article in the Scottish Federation of Housing Association (SFHA) magazine (Leblanc and Thomson, 2012). The Director asked the researchers to develop an improved sustainability strategy at the strategic level for the HA and to reflect the SKMS for their planned works projects. Being asked to undertake this work, demonstrated the

Director's faith in the research strategy and methods deployed and they have applied the strategic sustainability strategy in practice and are piloting the SKMS for their planned works projects.

\section{Conclusions}

This research provides a management strategy for practitioners embedded in delivering enhanced levels of sustainability within HA planned works to engage and utilise with sustainability-related knowledge more effectively. Despite a growing need for HA's to respond to this agenda within their practices, its implications for planned works remains poorly understood and under-researched resulting in the methodology for developing the strategy needed to reflect the realities of practice by focusing on a variety of practice based case studies. Knowledge mapping was applied to understand the flow of knowledge during 
HA planned works within four case studies and provided a SKMS consisting of recommendations for improving mechanisms of capture, storage, retrieval and exchange of sustainability-related knowledge.

The research was faced with a methodological challenge to ensure that the knowledge mapping represented the complex, dynamic and socially constructed nature of sustainabilityrelated knowledge whilst at the same time ensuring that it aligned with the specific requirements of delivering HA planned works. A knowledge mapping approach guided by a interpretivist perspective was developed in order to ensure the socially constructed nature of sustainability-related knowledge is reflected. However, paradigm interplay was drawn upon to enable accepted functionalist categories of knowledge (i.e. explicit, implicit, and tacit), sustainability dimensions and established planned work activities to help guide the coding and categories formed within the emerging knowledge maps. In drawing on established concepts and familiar activities the comparability between case studies and the wider applicability of the strategy between HA's should be enhanced. Care is taken to ensure that the dynamic nature of sustainability-related knowledge is not lost when considering functionalist categories, and that new categories are allowed to emerge, thus retaining the principles of the knowledge spiral and retaining the context of each planned works (Nonaka and Takeuchi, 1995). Although paradigm interplay is a contested approach presenting benefits and challenges methodologically, the authors feel in this case it enables knowledge mapping to better reflect practitioners 'realities' of practice by engaging with established concepts, language and activities (Leblanc and Thomson, 2012), but that needs to be framed within an overarching interpretivist perspective. The knowledge mapping exercises revealed the SKMS strategy needs to support knowledge transformation by supporting and fostering mechanisms for the exchange, storage and retrieval of sustainability-related knowledge. 
The research proposes a practical solution for HA practitioners struggling to implement sustainability within their day-to-day activities within planned works, and showcases the role of knowledge mapping as a technique for fostering an understanding of the management requirements necessary to develop a KM strategy. The SKMS proposes to HA practitioners recommendations for improving the general HA strategy and every planned works phase/activity considering the social, economic and environmental sustainability dimensions and different forms of knowledge (explicit, implicit and tacit). The SKMS does not replicate all HA contexts but reflects the most dominant within the sector by focusing on four specific HAs and SKMS developed with sufficient flexibility for practitioners to tailor it to their context. Further work could extend the SKMS applicability to all HAs and its implementation within planned works activities.

Finally, in terms of sustainability agenda, the research addresses the growing governmental pressure for social, economic and environmental sustainability in every activity of HA housing such as planned works, with high transferability of lessons to other social housing contexts and the wider construction industry. Indeed, the methodological approach and specific knowledge mapping techniques developed within this research have the potential to inform the development of a SKMS for a wide variety of construction-related processes and projects.

\section{References}

Audit Commission (2010) Tackling the financial challenge for councils of an ageing population, Audit Commission: National Statistics.

Al-Ghassani AM, Kamara FM, Anumba CF and Carrillo PM (2004) An innovative approach to identifying knowledge management problems. Engineering, Construction and Architectural Management, 11(5): pp. 349-357. 
Awad EM and Ghaziri HM (2003) Knowledge management, Prentice Hall, Harlow.

BERR (2008) Strategy for sustainable construction. Department of Business, Enterprise and Regulatory Reform. See: http://www.bis.gov.uk/files/file46535.pdf (accessed 04/06/14).

Carter K and Fortune C (2008) A consensual sustainability model: a decision support tool for use in sustainable building project procurement. Royal Institution of Chartered Surveyors Research Paper Series, 7(19), RICS.

Christie C (2011) Report on the future delivery of public services. The Christie Commission, Scottish Government.

CSanD (2011) Creating, sustaining and disseminating knowledge for sustainable construction: tools, methods and architecture, See: http://www.c-sand.org.uk/index.htm (accessed 04/06/14).

Egbu CO (2004) Managing knowledge and intellectual capital for improved organisational innovations in the construction industry: an examination of critical success factors. Engineering, Construction and Architectural Management, 11(5): 301-315.

Egbu CO (2006) Knowledge mapping and knowledge communication in decision making and for providing effective solutions for a sustainable urban environment. In: Proceedings of Construction and Building Research Conference (COBRA), (Sivyer E (ed)). The Bartlett School, University College London, London, UK.

Eppler MJ (2008) Classifying knowledge maps: typologies and application examples. In Knowledge Management Strategies: a handbook of applied technologies, (Lytras MD, Russ MA, Maier R and Naeve A (eds)). IGI Global, pp. 116-142. 
Fenner RA, Ainger CA, Cruickshank HJ, and Guthrie P (2006) Widening horizons for engineers: addressing the complexity of sustainable development, Proceedings of the Institute of Civil Engineers, Engineering Sustainability, 159(4), pp. 145-154.

Fisher KM, Wandersee JH and Moody DE (2001) Mapping biology knowledge. Science and technology education library, Kluwer academic publishers, AA Dordrech, The Netherlands.

Folkes CR (2004) Knowledge mapping: Map types, Contexts and uses. Open University working paper KM-SUE 4, Prepared for the EPSRC project: Knowledge mapping and bringing about change for the sustainable urban environment (KM-SUE).

Frappaolo C (2008) Implicit knowledge. Knowledge Management Research and Practice, 6, pp. 23-25.

General Registers Office Scotland (2010) Census and Population projects for 2010. Scottish Government, GROS.

Glaser B and Strauss A (1967) The discovery of grounded theory: strategies of Qualitative research. Wiedenfeld and Nicholson, London.

Gioia DA and Pitre E (1990) Multiparadigm perspectives on theory building. Academy of Management Review, 15, pp. 584-602.

Guo Z and Sheffield J (2006), A Paradigmatic and Methodological Examination of KM Research: 2000-2004. Proceedings of the 39th Annual Hawaii International Conference on System Sciences, IEEE Computer Society Press.

Hall M and Purchase D (2006) Building or Bodging? Attitudes to sustainability in UK public sector housing construction development. Sustainable Development, 14(3), pp. 205-218. 
Hamel G and Pralahad CK (1994) Competing for the future, Harvard Business School Press, Cambridge, Mass.

Harriott S and Matthews L (2004) Introduction to Social Housing. Chartered Institute of Housing, London.

Hassard J (1988) Overcoming hermeticism in organisation theory: an alternative to paradigm incommensurability. Human Relations, 41, pp. 247-259.

Housing Corporation (2003) Sustainable Development Strategy. in International Union for Conservation of Nature (1980) World Conservation Strategy, Gland, Switzerland. Jones K and Cooper J (2007) The role of routine maintenance in improving the sustainability of existing social housing, in Proceedings of the ENHR International Conference on Sustainable Urban Areas, Rotterdam, 25-28 June.

Kasvi JJJ, Vartiainen M and Hailikari M (2003) Managing knowledge and knowledge competencies in projects and project organisations. International Journal of Project Management, 21(8), pp. 571-582.

Leblanc H and Thomson C (2012) Paradigm interplay to develop a sustainability related knowledge management strategy In: Smith, S.D (Ed) Procs 28th Annual ARCOM Conference, 3-5 September 2012, Edinburgh, UK, Association of Researchers in Construction Management, pp. 1145-1155.

Leblanc H, Thomson C, Cameron I and Nitithamyong P (2013) Developing a planned works process model for Scottish housing associations. Engineering, Construction and Architectural Management, 20(3), pp. 232-249. 
Lichtenstein S and Swatman PMC (2003) Sustainable knowledge management systems: Integration, personalisation and contextualisation. In Proceedings of 11th European Conference on Information Systems, Naples, Italy, 1-8, See:

http://dro.deakin.edu.au/eserv/DU:30005156/lichtenstein-sustainableknowledge-2003.pdf (accessed 04/06/14).

Malone TF and Yohe GW (2002) Knowledge partnerships for a sustainable, equitable and stable society. Journal of Knowledge Management, 6(4), pp. 368-378.

Matsumoto IT, Stapleton J, Glass J and Thorpe T (2005) A knowledge-capture report for multidisciplinary design environments. Journal of Knowledge Management, 9(3), pp. 83-92.

McCagg EC and Dansereau DF (1991) A convergent paradigm for examining knowledge mapping as a learning strategy. Journal of Educational Research, 84(6), pp. 317-324.

Nonaka I and Takeuchi H (1995) The knowledge creating company: how Japanese companies create the dynamics of innovation, Oxford University press. Oxford.

O’Donnell AM, Dansereau DF and Hall RH (2002) Knowledge maps as scaffolds for cognitive processing. Educational Psychology Review, 14(1), pp. 71-86.

Offsey S (1997) Knowledge management: linking people to knowledge for bottom line results. Journal of Knowledge Management, 1(2), pp. 113-122.

Power A (2010) Housing and Sustainability: demolition or refurbishment? Proceedings of the ICE - Urban Design and Planning, 163(4), pp. 205-216.

Renukappa S and Egbu C (2007) The key challenges associated with mapping sustainabilityrelated knowledge for organisation competitiveness: an empirical study, In Information and 
KM-Helping the Practitioner in Planning and Building (Lima CP and Bauer M (eds)), Fraunhofer IRB Verlag, Stuttgart, pp. 335-344.

Rice PL and Ezzy D (1999) Qualitative research methods, a health focus. Oxford University Press, Melbourne.

Scavarda AJ, Bouzdine-Chameeva T, Goldstein SM, Hays JM, Hill AV (2004) A review of the causal mapping practice and research literature. In Proceedings of Second World Conference on POM and l5th Annual P0M Conference, Cancun, Mexico, April 30 - May 3.

Schultze U (1998) Investigating the Contradictions in Knowledge Management. In IFIP WG8.2 \& WG8.6 Joint Working Conference on Information Systems: Current Issues \& Future Changes, Helsinki, Finland, pp. 155, Omnipress, Wisconsin, USA

Sharp M and Jones K (2012) Perceived inefficiency of social housing maintenance. Construction Innovation, 12(4), pp. 414-428.

Shelbourn MA, Bouchlaghem DM, Anumba CJ, Carillo PM, Khalfan MK and Glass J (2006) Managing knowledge in the context of sustainable construction. ITcon, 11, pp. 57-71.

Strauss A and Corbin J (1990) Grounded theory in practice, Sage publications, London.

Strategic Forum for Construction (2008) Strategic forum for construction, See:

http://www.strategicforum.org.uk/ (accessed 04/06/14).

Sullivan L (2007) A low carbon building standards strategy for Scotland, Arcmedia, Scotland.

Sustainable Homes (2007) A guide to developing a sustainability strategy and action plan, See: http://www.sustainablehomes.co.uk/ (accessed 04/06/2014). 
The Scottish Government (2013) Energy Efficiency Standard for Social Housing. SEA Environmental Report, See: http://www.scotland.gov.uk/Topics/BuiltEnvironment/Housing/sustainable/standard/eesshseaenvironmentalreport2 (accessed 04/06/14).

The Scottish Government (2011) Housing statistics for Scotland-key information and summary tables, See: http://www.scotland.gov.uk/Topics/Statistics/Browse/HousingRegeneration/HSfS/KeyInfoTables (Accessed 04/06/14).

The Scottish Housing Regulator (2010) Registered Social Landlords in Scotland summary facts and figures 2008/2009, See:

http://www.scottishhousingregulator.gov.uk/stellent/groups/public/documents/webpages/shr_ registeredsociallandlordsi.pdf (accessed 04/06/14).

Thomson CS, El-Haram MA and Emmanuel R (2011) Mapping sustainability assessment with the project lifecycle. Proceedings of the Institution of Civil Engineers Engineering Sustainability, 164(1), pp. 143-157.

Thomson CS, El-Haram MA and Emmanuel R (2010) Mapping knowledge flow during sustainability assessment. Proceedings of the Institution of Civil Engineers, Urban Design and Planning, 163(2), pp. 67-78.

Turcotte D and Geiser K (2010) A framework to guide sustainable housing development. Housing and Society, 37(2), pp. 87-117

UK Green Building Council (2008) Low Carbon Existing Homes. Green Building Council and Project Partners, London. 
Vail E (1999) Mapping organisational knowledge. Knowledge Management Review, 8, May/June, pp. 10-15.

Vanegas JA, DuBose JR and Pearce AR (1995) Sustainable technologies for the building construction industry. Proceeding of Symposium on Design for the Global Environment, Atlanta GA, November 2-4.

Venters W (2002) Literature review for C-Sand, CSand. See: http://www.csand.org.uk/documents/wp1001-02-KMLitRev.pdf (accessed 04/06/14)

World Commission on Environment and Development (WCED) (1987) Our Common Future. Oxford University Press, Oxford.

Williams K and Dair C (2006) What is stopping sustainable buildings in England? Barriers experienced by stakeholders in delivering sustainable developments. Sustainable Development, 15(3), pp. 135-147.

Willmott H (1993) Breaking the paradigm mentality. Organizational studies, 14, pp. 681721.

Wolstenholme A (2009) Never waste a good crisis a review process since rethinking construction and thoughts for our future, Constructing Excellence in the Built Environment, See: www.constructingexcellence.org.uk/pdf/Wolstenholme_Report_Oct_2009.pdf (accessed $04 / 06 / 14)$ 
Appendix 1: Glossary for abbreviations found in body of paper

\begin{tabular}{|l|l|}
\hline Full expression & Abbreviation \\
\hline Housing association & HA \\
\hline Knowledge Management & KM \\
\hline Knowledge Map & Kmap \\
\hline Key Performance Indicators & KPI \\
\hline Local Authority's & LA \\
\hline Observations for Improvement & OFI \\
\hline Propositions for improvement & PFI \\
\hline Planned maintenance officer & PMO \\
\hline Planned Works Process Model & PWPM \\
\hline Suggestions for improvement & SFI \\
\hline Sustainable-related Knowledge Management Strategy & SKMS \\
\hline Technical Management Services & TMS \\
\hline Registered Social Landlords & RSL \\
\hline
\end{tabular}

${ }^{*}$ further abbreviations provided for respondents in table 4, but these not referred to in text 
Appendix 2: HA Planned Works Process Model (Leblanc et al., 2013)

\begin{tabular}{|c|c|}
\hline \multicolumn{2}{|r|}{ PWPM } \\
\hline Phase & Mainstream activities \\
\hline Planning & $\begin{array}{ll}\text { - } & \text { Establishment of work priorities } \\
\text { - } & \text { Budget } \\
\end{array}$ \\
\hline Contract preparation & $\begin{array}{ll}\text { - } & \text { Project details and work specifications } \\
\text { - } & \text { Housing survey } \\
\end{array}$ \\
\hline Tendering & - Contractor selection \\
\hline Site preparation & $\begin{array}{ll}\text { - } & \text { Tenants consultation } \\
\text { - } & \text { Asbestos survey (detailed) } \\
\text { - } & \text { Survey/scoping or March-in } \\
\text { - } & \text { Pre-start meeting } \\
\end{array}$ \\
\hline On site work & $\begin{array}{ll}\text { - } & \text { Work execution } \\
\text { - } & \text { Contactor (quality) inspection } \\
\text { - } & \text { Sign off / handover }\end{array}$ \\
\hline Post site & $\begin{array}{ll}\text { - } & \text { Closing meeting } \\
\text { - } & \text { Contractor evaluation process/assessment }\end{array}$ \\
\hline Phase/activity & Occasional activities \\
\hline Any & $\begin{array}{ll}\text { - } & \text { Innovative project decision/selection } \\
\text { - } & \text { Asbestos survey (high level) } \\
\text { - } & \text { Manufacturer selection } \\
\text { - } & \text { Stock condition survey } \\
\text { - } & \text { Consultant selection } \\
\end{array}$ \\
\hline Work execution & - Change of instruction \\
\hline Phase/activity & Recurrent activities \\
\hline All & $\begin{array}{ll}\text { - } & \text { Committee meeting/tenant panel meeting } \\
\text { - } & \text { Stock condition/ validation survey } \\
\text { - } & \text { Contractor selection } \\
\end{array}$ \\
\hline Work execution & $\begin{array}{l}\text { - } \quad \text { Monthly/weekly progress meeting } \\
\text { - } \quad \text { Monthly contractor meeting } \\
\text { - } \quad \text { Monthly contractor estimation } \\
\end{array}$ \\
\hline
\end{tabular}




\section{Appendix 3: Sustainability-related knowledge management strategy for HA planned works.}

\begin{tabular}{|c|c|c|c|c|}
\hline \multicolumn{5}{|c|}{ SUSTAINABILITY-RELATED KM STRATEGY FOR HA PLANNED WORKS } \\
\hline \multicolumn{5}{|c|}{ OFI, SFI and PFI for HA general strategy } \\
\hline \multicolumn{5}{|c|}{ 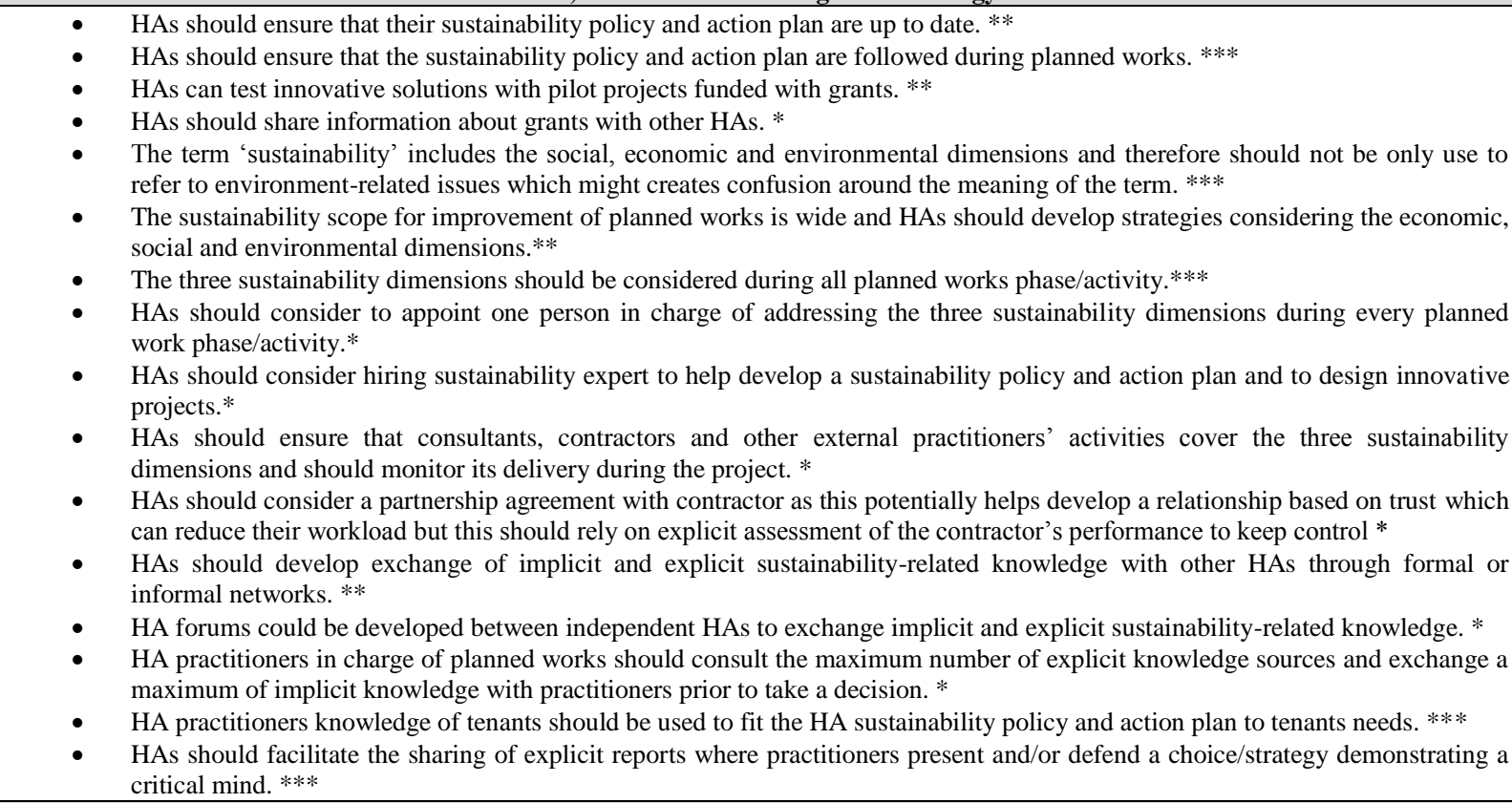 } \\
\hline \multicolumn{5}{|c|}{ OFI, SFI and PFI for mainstream activity } \\
\hline Planning & $\begin{array}{l}\text { - Establishment } \\
\text { of work } \\
\text { priorities } \\
\text { - Budget }\end{array}$ & $\begin{array}{l}\text { - HAs involving tenants during the planning } \\
\text { phase should be careful that tenants consider } \\
\text { the HA first before their personal interests.* } \\
\text { - In addition to the consultation of the HA } \\
\text { long term plan of work and stock condition } \\
\text { information system, HA practitioners should } \\
\text { meet with colleagues having relevant } \\
\text { knowledge prior to establishing the work } \\
\text { priorities.** } \\
\text { Grouping works planned in different years } \\
\text { might improve the social and economic } \\
\text { sustainability dimensions of the long term } \\
\text { plan of work strategy. This strategy is } \\
\text { particularly suitable to HA in long term } \\
\text { partnership with contactor. * } \\
\text { HAs should consider software to manage } \\
\text { general stock condition surveys and detail } \\
\text { works information which can be useful } \\
\text { when establishing work priorities. ** } \\
\text { HAs should consider consultants offering } \\
\text { the consultation of stock condition survey } \\
\text { information online which eliminates the } \\
\text { need for a HA general stock information } \\
\text { software and associated manipulation of } \\
\text { information. * }\end{array}$ & 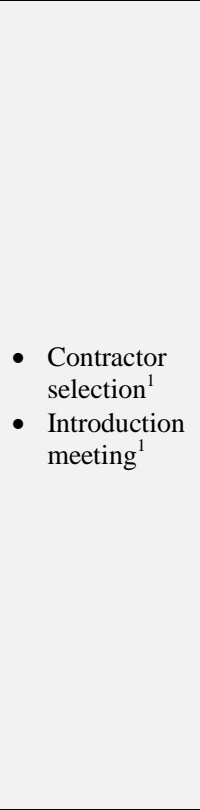 & $\begin{array}{l}\text { - Large HAs should } \\
\text { include } \\
\text { environmental } \\
\text { KPI's in liaison } \\
\text { with the } \\
\text { sustainability } \\
\text { policy and action } \\
\text { plan to assess the } \\
\text { contractor } \\
\text { performance and } \\
\text { distribute the } \\
\text { work.*** }\end{array}$ \\
\hline \multirow{2}{*}{$\begin{array}{l}\text { Contract } \\
\text { preparation }\end{array}$} & $\begin{array}{l}\text { - Project details } \\
\text { and work } \\
\text { specifications }\end{array}$ & $\begin{array}{l}\text { - HAs should (or require the consultant to) } \\
\text { link the 'project details and work } \\
\text { specifications' activity to the HA } \\
\text { sustainability policy and action plan. } * * *\end{array}$ & \multirow{2}{*}{$\begin{array}{l}\text { - Pre-contract } \\
\text { meeting }^{1}\end{array}$} & \multirow{2}{*}{$\begin{array}{l}\text { - Large HAs should } \\
\text { introduce } \\
\text { sustainability in } \\
\text { the contract } \\
\text { preparation phase } \\
\text { by linking it to the } \\
\text { HA sustainability } \\
\text { policy and action } \\
\text { plan. } * * *\end{array}$} \\
\hline & $\begin{array}{l}\text { - Housing } \\
\text { survey }\end{array}$ & $\mathrm{X}$ & & \\
\hline Tendering & $\begin{array}{l}\text { - } \begin{array}{l}\text { Contractor } \\
\text { selection }\end{array} \\
\end{array}$ & $\begin{array}{l}\text { - HAs should consider the environmental dimen } \\
\text { dimensions during the tendering phase and ass }\end{array}$ & ess it during the $p$ & $\begin{array}{l}\text { the economic and social } \\
\text { in a similar way. } * * *\end{array}$ \\
\hline \multirow{2}{*}{$\begin{array}{l}\text { Site } \\
\text { preparation }\end{array}$} & \multicolumn{4}{|c|}{$\begin{array}{l}\text { HA should investigate potential environmentally related criteria during the site preparation phase and link it to the HA } \\
\text { sustainability policy and action plan. } * * *\end{array}$} \\
\hline & - Tenants & & & \\
\hline
\end{tabular}




\begin{tabular}{|c|c|c|}
\hline & consultation $^{1}$ & $\begin{array}{l}\text { and to view and choose components. However, HAs should ensure that the data and opening } \\
\text { hours of such event suit tenants' availability. }{ }^{* *} \\
\text { HA organising tenants' event should encourage the exchange of HA practitioners' tacit } \\
\text { knowledge about tenants in order to establish the most appropriate date and opening hours. }{ }^{*}\end{array}$ \\
\hline & $\begin{array}{l}\text { - Asbestos } \\
\text { survey } \\
\text { (detailed) })^{3}\end{array}$ & $\mathrm{X}$ \\
\hline & $\begin{array}{l}\text { - Survey/scoping } \\
\text { or March-in }\end{array}$ & $\begin{array}{l}\text { - HAs should encourage the contractor/manufacturer to propose component packages to tenants } \\
\text { and therefore take advantage of the economies of scale. }{ }^{*} \\
\text { HA should ensure that tenants understand contractors that use computerised drawings to } \\
\text { explain the design of a new kitchen and therefore justify the potential additional cost of this } \\
\text { technique compared to hand drawing. * }\end{array}$ \\
\hline & 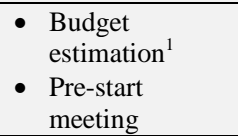 & $\mathrm{X}$ \\
\hline \multirow{4}{*}{ On site work } & \multicolumn{2}{|c|}{$\begin{array}{l}\text { - HA should advertise the right to compensation for improvement and make sure tenants carrying out work } \\
\text { respect the health and safety regulations. *** } \\
\text { HA should link the on site work phase with the HA sustainability policy and action plan and monitor and asses } \\
\text { contractor recycling policy application. * } \\
\text { HA should encourage and ensure relatively easy informal exchange of implicit knowledge between } \\
\text { practitioners during the on site work phase such as phone calls. * }\end{array}$} \\
\hline & $\begin{array}{l}\text { - Work } \\
\text { execution }\end{array}$ & $\begin{array}{l}\text { - Response rates can be improved by merging tenant surveys with the disruption allowance } \\
\text { declaration and/or organising a cash prize draw for tenants who completed the survey ** } \\
\text { - Large HAs collecting tenant satisfaction surveys during the 'sign-off' activity should find } \\
\text { incentives for tenants to fill out the questionnaire prior the activity to minimise the activity } \\
\text { duration. *** } \\
\text { - HA delivering decoration allowance should ensure that tenants use the allocated funds for the } \\
\text { purpose of decorating the property and for no other purpose.*** } \\
\text { HA might reduce or eliminate the amount of disruption allowance allocated in order to carry } \\
\text { out more capital works and delivering fully finished rooms. ** }\end{array}$ \\
\hline & $\begin{array}{l}\text { - Contactor } \\
\text { (quality) } \\
\text { inspection } \\
\end{array}$ & $\mathrm{X}$ \\
\hline & $\begin{array}{l}\text { - Sign off / } \\
\text { handover }\end{array}$ & $\begin{array}{l}\text { - HA should allow tenants a reasonable amount of time between the completion of jobs, HA } \\
\text { inspection and tenants surveys to report potential faults. ** }\end{array}$ \\
\hline \multirow{3}{*}{ Post site } & $\begin{array}{l}\text { - Closing } \\
\text { meeting }\end{array}$ & $\begin{array}{l}\text { - HAs practitioners in charge of planned works should consider discussing KPIs with the } \\
\text { contractor which might increase the contractor performance on the next project. * }\end{array}$ \\
\hline & $\begin{array}{l}\text { Contractor } \\
\text { evaluation } \\
\text { process/ } \\
\text { assessment }\end{array}$ & $\begin{array}{l}\text { KPIs should include the environmental sustainability dimension. } * * * \\
\text { KPIs should be rated by more than one practitioner and should be the result of an implicit } \\
\text { knowledge exchange between the HA practitioner in charge of planned works and other } \\
\text { practitioners such as the consultant. } * * *\end{array}$ \\
\hline & \multicolumn{2}{|c|}{ HAs should formally follow up and assess the performance of installed components such as heating systems.*** } \\
\hline \multicolumn{3}{|r|}{ OFI, SFI and PFI for occasional activity } \\
\hline Phase/activity & Activity & \multirow[b]{2}{*}{$\begin{array}{l}\text { - HAs should link the development of innovative projects with the goal of improving tenan } \\
\text { properties and testing renewable energy to the HA sustainability policy and action plan. ** } \\
\text { HAs should exchange information on existing grants to carry out pilot projects testing } \\
\text { innovative solutions such as renewable energy that do not offer currently value for money } \\
\text { compared to traditional systems. } * * * \\
\text { HA practitioners in charge of the 'innovative project selection' should consult a maximum } \\
\text { number of knowledge sources but if the activity workload appears disproportionate they should } \\
\text { also consider hiring an expert which potentially increases the chances of securing funding for a } \\
\text { grant. } * * * \\
\text { HA practitioners in charge of planned works should save in a database (explicit form) the } \\
\text { information and knowledge about innovative projects gathered during conferences, informal } \\
\text { discussions with colleagues or within magazines.*** } \\
\text { HA practitioners in charge of selecting the tenants to participate in pilot projects should discuss } \\
\text { such project with other practitioners who have also knowledge of tenants. *** }\end{array}$} \\
\hline \multirow{5}{*}{ Any } & $\begin{array}{l}\text { Innovative project } \\
\text { selection }\end{array}$ & \\
\hline & Asbestos survey & $\begin{array}{l}\text { - HAs should consider carrying out a detailed asbestos survey prior to any work and to consider } \\
\text { the potential inefficiency of an asbestos register based on high level asbestos survey. ** }\end{array}$ \\
\hline & $\begin{array}{l}\text { Manufacturer } \\
\text { selection }\end{array}$ & $\begin{array}{l}\text { - HAs should consider the three sustainability dimensions during the 'manufacturer selection' } \\
\text { activity including the source of materials, tenants opinion and manufacturer location. *** } \\
\text { Practitioner in charge of 'manufacturer selection' activity should consider implicit exchange of } \\
\text { knowledge with a maximum number of sources possessing tacit knowledge about it including } \\
\text { tenants. } * * *\end{array}$ \\
\hline & $\begin{array}{l}\text { Stock condition } \\
\text { survey }^{5}\end{array}$ & $\begin{array}{l}\text { - HAs carrying out a full stock condition survey should discuss with other association or experts } \\
\text { the scope of information to be collected and should include social and environment dimensions } \\
\text { within this activity.*** }\end{array}$ \\
\hline & $\begin{array}{l}\text { Consultant } \\
\text { selection }^{4}\end{array}$ & $\begin{array}{l}\text { - HAs practitioners in charge of consultant selection should discuss it with other practitioners } \\
\text { and integrate the three sustainability dimensions within consultants' scope of work. } * * *\end{array}$ \\
\hline
\end{tabular}




\begin{tabular}{|c|c|c|}
\hline $\begin{array}{l}\text { Work } \\
\text { execution }\end{array}$ & $\begin{array}{l}\text { Change of } \\
\text { instruction }\end{array}$ & $\begin{array}{l}\text { - The 'change of instruction' activity should address in addition of the economic dimension, the } \\
\text { social and environmental dimensions and to be linked to the HA sustainability policy and } \\
\text { action plan. } * * *\end{array}$ \\
\hline \multicolumn{3}{|r|}{ OFI, SFI and PFI for recurrent activity } \\
\hline \multirow{3}{*}{ All } & $\begin{array}{l}\text { Tenants } \\
\text { committee/panel } \\
\text { meeting }\end{array}$ & $\begin{array}{l}\text { - HAs should store and facilitate access to tenants' committee meetings reports since they } \\
\text { represent an explicit source of sustainability knowledge. } * * *\end{array}$ \\
\hline & $\begin{array}{l}\text { Stock condition } \\
\text { survey/ validation } \\
\text { survey }\end{array}$ & $\begin{array}{l}\text { - Stock condition survey can be carried out by a consultant or added the work loads of HA } \\
\text { staff(s) regularly accessing tenant properties. } * * \\
\text { - Social and economic criteria should be added to the existing economic criteria within the stock } \\
\text { condition survey. } * * *\end{array}$ \\
\hline & $\begin{array}{l}\text { Contractor } \\
\text { selection }^{6}\end{array}$ & $\begin{array}{l}\text { - HA practitioner selecting a contractor should consult a maximum number of knowledge } \\
\text { sources and if they lack of time or expertise should consider the selection of a consultant. *** } \\
\text { - HA should ensure that the contractor's scope of work covers the three sustainability } \\
\text { dimensions and this is monitored during the project. *** }\end{array}$ \\
\hline \multirow{3}{*}{$\begin{array}{l}\text { Work } \\
\text { execution }\end{array}$} & $\begin{array}{l}\text { Monthly progress } \\
\text { meeting }\end{array}$ & $\begin{array}{l}\text { - HAs should emphasise the exchange of sustainability-related knowledge during progress } \\
\text { meetings and to make the meeting minutes easily retrievable. } * *\end{array}$ \\
\hline & $\begin{array}{l}\text { Monthly } \\
\text { contractor } \\
\text { meeting }^{1}\end{array}$ & $\begin{array}{l}\text { - HAs should emphasise the exchange of sustainability-related knowledge during monthly } \\
\text { contractor meetings and facilitate access to meeting minutes. } * * *\end{array}$ \\
\hline & $\begin{array}{l}\text { Monthly } \\
\text { contractor } \\
\text { estimation }^{1}\end{array}$ & $\begin{array}{l}\text { - HAs managing planned works projects over several months should request a monthly } \\
\text { estimation from contractors in order to keep control of the project cost. * }\end{array}$ \\
\hline \multicolumn{3}{|c|}{ 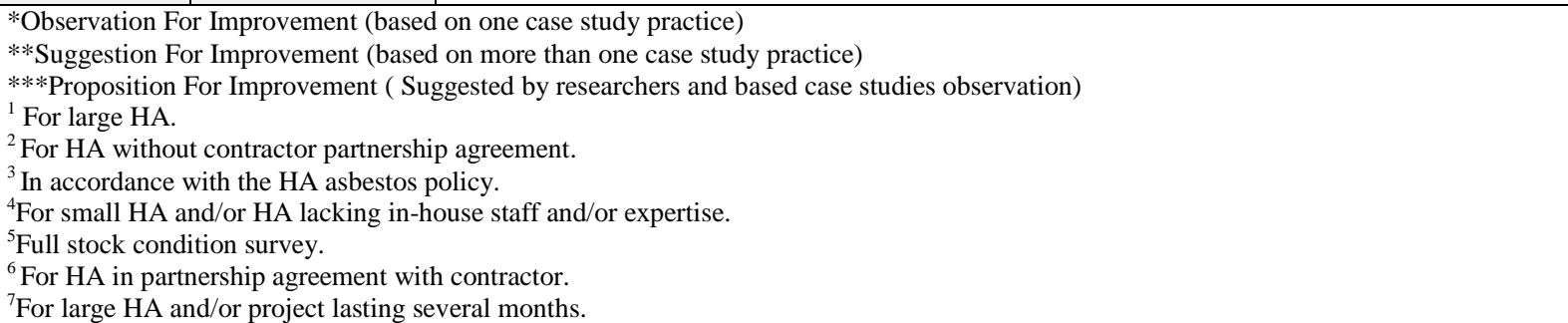 } \\
\hline
\end{tabular}

